\title{
The Linkage between Economic Growth and Openness: Does Financial Development Matter?
}

\author{
Burçak POLAT iD a \\ a Siirt University, Business and Economics Faculty, Department of Economics, Siirt, Turkey. burcakpolat@hotmail.com, \\ burcakpolat@siirt.edu.tr
}

\begin{tabular}{|c|c|}
\hline ARTICLE INFO & ABSTRACT \\
\hline Keywords: & \multirow{4}{*}{$\begin{array}{l}\text { Purpose: Even though, the impact of trade openness on economic growth overwhelmingly has } \\
\text { been analyzed by researchers; the real effect still remains inconclusive and controversial in the } \\
\text { literature. The main objective of this study is therefore to find out whether the financial } \\
\text { development has any role in determining the impact of trade openness on economic growth }\end{array}$} \\
\hline International Trade & \\
\hline Trade Openness & \\
\hline Economic Growth & \\
\hline Financial Development & $\begin{array}{l}\text { Method: The study has employed dynamic panel data of } 41 \text { developing countries for the period } \\
\text { 1995-2014. }\end{array}$ \\
\hline Received 15 September 2018 & \multirow{3}{*}{$\begin{array}{l}\text { Findings: this study could not find any effect of trade openness or financial development on } \\
\text { economic growth. Rather, the study has found that interaction term representing the joint effect } \\
\text { of financial development and openness has a negative effect on economic growth. Furthermore, } \\
\text { the study has empirically proved that human capital and investments have positive effects on } \\
\text { economic growth while inflation rate and global financial crisis worsen the economic growth. }\end{array}$} \\
\hline Revised 19 January 2019 & \\
\hline Accepted 25 January 2019 & \\
\hline Article Classification: & \multirow{2}{*}{$\begin{array}{l}\text { Discussion: The study has attributed this result to the willingness of investors to transfer their } \\
\text { financial capital outflows as trade barriers lowers and financial system gets deeper. }\end{array}$} \\
\hline Research Article & \\
\hline
\end{tabular}

\section{1- Introduction}

Even though, the impact of trade openness on economic growth overwhelmingly has been analyzed by researchers, the real effect still remains inconclusive and controversial in the literature. There are two opposite views have been debated so far. On one side, some of the researchers argue that trade openness may promote economic growth; on the other side, others claim that trade openness may be detrimental to economic growth.

Trade openness enables investors to access new technology abroad which in turn increase the productivity of investments, and facilitate a country's specialization in research-incentive products. Furthermore, more open economies force multinational firms to be more competitive to survive in the international trade compared to domestic markets which in turn stimulate economic growth. See the studies of Romer (1989), Ades and Glaeser (1999) and Baldwin et al. (2005).

On the contrary, some studies claim that trade openness may be harmful for economic growth. International market increases competitiveness and thus decreases expected profits thereby discourage research and development $(R \& D)$ activities and innovation. Moreover, as countries become more open to the rest of the world, they may specialize in sectors that they have disadvantage or in sectors in which technological innovations or learning by doing are exhausted. See the studies of Lucas (1988), Young (1991), Redding (1999), Yenikkaya (2003) and Sarkar (2008).

Furthermore, the impact of trade openness on economic growth may depend on other factors such as the level of development of the countries or sectoral differences. For-example, Lucas (1988) has claimed that technological diffusion may vary across sectors and trade may affect the growth of aggregate productivity if opportunities for learning by doing vary across sectors. Furthermore, Abramovitz (1986) and Howitt (2000) 
have argued that advances economies are more able to absorb new technology from abroad so that trade openness promotes economic growth. Even though, the concept of economic growth is relatively broad and there are many other factors that may affect the contribution of trade openness to economic growth (forexample level of economic development or sectoral differences etc.), this study aims to find out whether the development of financial system alters the impact of trade openness to economic growth.

The main objective of this study is therefore to explore contribution of financial development in 41 developing countries ${ }^{1}$ from1995 to 2014 . The contribution of the study to the existing literature can be explained as follows: First, new growth theories perceive technology as endogenous variable rather than exogenous variable; thus we have employed Generalized Method of Moments (GMM) dynamic panel data estimators to capture edogeneitiy between explanatory variables and dependent variable. Second, within simultaneous equation system, we are able to find out if development of financial system weakens or strengths the contribution of trade openness to the economic growth. Third, we are able to predict if there is a linkage between trade openness and economic growth.

The rest of the paper is organized as follows: Second section explains the linkages between finance, growth and openness. Following second section, third section discusses the literature. Forth section explains the data and methodology. Fifth section interprets the empirical findings and last section concludes the study.

\section{2- Finance, Economic Growth and Trade Openness: Theory}

The relationship between financial deepness and economic growth may take different forms. There are two types of hypothesis that links financial system to the economic growth. These hypotheses are known as supply-leading hypothesis and demand -following hypothesis. With respect to the supply-leading hypothesis; financial sector may lead to economic growth through accumulation channel and allocation channel. The accumulation channel emphasizes the finance-induced growth effects of human and capital accumulation. On the other hand, the allocation channel emphasizes finance-induced economic growth through efficiency gains in resource allocation. With regards to demand-following hypothesis, economic growth may lead to development in financial system. For-example, in a growing economy, private sector may demand different and more efficient financial instruments and improved excess to external finance. Financial sector and growth may be mutually dependent. Private sector may supply necessary funds by their savings that enhance the financial system; improved financial system may in return lead to economic growth through supply channel. Furthermore, financial sector and growth may be independent each other.

A potential relationship between trade openness and financial sector opens up new channels through which financial system may interact with private sector. Better financial systems may provide a comparative advantage for industrial sector that rely on heavily external financing. Thus, countries with developed financial market are expected to show commercial structure linked to finance dependent industry sector in the international arena. On the other hand, higher trade openness increases the demand for different financial instruments. For-example, multinational firms may demand for different financial products to avoid risk or reduce risk in the international market. If trade openness induces for more financial deepening, financial development may lead economic growth through supply leading-hypothesis which discusses earlier. Thus, developed financial system may strength the contribution of trade openness to economic growth. On the other side, if finance induces trade openness, higher trade openness is expected to stimulated economic growth.

\section{3- Literature Review}

Analysis of literature reveals that most of the previous studies have focused the linkage between trade openness and economic growth or the linkage between financial development and economic growth. There is almost a handful of study that examines the impact of financial development on the contribution of trade openness to economic growth.

\footnotetext{
${ }^{1}$ These developing countries are Albania, Argentina, Armenia, Azerbaijan, Bangladesh, Bolivia, Botswana, Brazil, Cameroon, China, Colombia, Congo, Costa Rica, Cote d'Ivoire, Dominican Republic, Ecuador, Egypt, Honduras, India, Indonesia, Iran, Jamaica, Jordan, Kazakhstan, Kyrgyz Republic, Macedonia, Malaysia, Mexico, Morocco, Nepal, Nigeria, Pakistan, Panama, Peru, Philippines, Senegal, Sri Lanka, Thailand, Tunisia, Turkey and Yemen.
} 
Several studies examining the relationship between trade openness and economic growth found mixed evidence. Some researchers argued that trade openness promotes economic growth, while others support opposite view, still others could not find any relationship between these two variables. For-example, Awokuse (2008), Rao and Rao (2009), Ramanayake and Lee (2015), Sakyi et al. (2015), Keho (2017) have all argued that trade openness causes economic growth. On the other side, Sarkar (2008) has examined the linkage between trade openness and economic growth for a sample of 51 less developed countries. He has found that majority of the country group in the analysis experienced no positive long-term relationship between openness and growth during the 1961-2002 period. Ulaşan (2015) has investigated the opennessgrowth nexus in a dynamic panel data framework and found that lower trade barriers are not related with the economic growth.

Furthermore, as the linkage between openness and economic growth remains still inconclusive and complex, many researchers have examined whether there are economic conditions for stronger or weaker tradegrowth relationship. For-example, Harrison (1996), Yenikaya (2003), Dowrick and Golley (2004), Kim and Lin (2009) have claimed that level of economic development has an important role to determine the contribution of trade openness to economic growth. They have argued that more advanced economies tend to have better financial markets, $R \& D$ activities, and human capital accumulation so that they are more able to absorb new technology attained by doing business with the rest of the world. Kaltani (2007) has investigated the role of reforms in the link between trade openness and economic growth in Albania. He has concluded that financial depth, governance and infrastructure have crucial role to strength the contribution of openness to economic growth.

Stiglitz (2004) and Aghion et al. (2005) have pointed out the importance of development of financial system to strength the effect of trade openness on economic growth. They concluded that trade openness may encourage the development of R\&D activities and thus stimulate technological progress in the country. And an efficient financial system is needed to spur innovation by identifying and funding productive investments. Furthermore, Kim et al. (2012) have analyzed the interactions among economic growth, financial development and trade openness through simultaneous equation system. They have concluded that financial development has a positive effect on trade in developed countries while it has a negative effect on trade in poor countries. Yet, financial development stimulates trade openness in richer countries; the trade has an ambiguous impact on financial development. Moreover, Huang and Chang (2014) have investigated whether financial development is associated with stronger or weaker trade openness-growth relationship. They found out the countries with higher stock market development strength the contribution of trade openness to economic growth.

\section{4- Data and Methodology}

\subsection{Data}

We have determined Gross Domestic Product (GDP) per capita growth rate as of our dependent variable. We have selected three different measures as indicators of financial developments. These variables are namely domestic credit provided by financial sector (\% of GDP), domestic credit to private sector (\% of GDP) and Broad money (\% of GDP). While first two indicators show the financial deepness of banking system, broad money represents the money in the circulation outside of the banking system. Additionally, we have incorporated control variables that may have potential to affect the economic growth rates. These are namely GDP per capita, Openness index which is calculated taking the ratio of export plus imports summation to GDP, female labor force (\% of total labor force) as an indicator of human capital, gross capital formation (investment) and inflation rate. Lastly, we have also included dummy variables for the years of 2008 and 2009 to measure the effect of Global Financial Crisis (GFC) on economic growth. All variables have measured in US Dollars and attained from World Bank Data retrieval tool (www.worldbank.org.) Data statistics and expected signs of the coefficients are provided in Table 1 below. 
Table 1. Data Summary and Descriptive Statistics

\begin{tabular}{|l|c|c|c|c|}
\hline Variables & Observations & Mean & $\begin{array}{c}\text { Standard } \\
\text { Deviation }\end{array}$ & Expected Sign \\
\hline Growth (\%) & 820 & 2.9617 & 4.1135 & $(+)$ \\
\hline Financial Dev1 (\%) & 820 & 47.8504 & 35.9411 & $(+)$ \\
\hline Financial Dev2 (\%) & 820 & 36.7044 & 30.0818 & $(+)$ \\
\hline Financial Dev3 (\%) & 820 & 50.8088 & 32.7491 & $(+)$ \\
\hline GDP Per Capita & 820 & 30.5390 & 27.6679 & $(+/)$ \\
\hline Openness (\%) & 820 & 73.5726 & 35.8621 & $(+)$ \\
\hline Human Capital (\%) & 820 & 36.4596 & 9.6247 & $(-)$ \\
\hline Investment & 820 & 24.6350 & 7.7942 & 10.5658 \\
\hline Inflation (\%) & 820 & 8.1805 & & $($ ) \\
\hline
\end{tabular}

Note: Financial Dev1, 2 and 3 represent domestic credit provided by financial sector (\% of GDP), domestic credit to private sector (\% of GDP) and Broad money (\% of GDP) respectively. Human capital represents female labor force as (\% of total labor force)

As seen from Table 1, we don't have any missing observations in the series. With respect to the standard deviations of variables, indicators for financial developments, openness index and GDP per capita are seen as the most volatile variables. On the other side, human capital measured female labor forces as \% of total labor force is seen as the least volatile variable. Analysis of the mean of the variables reveals that the mean of the openness index is around 74 meaning that most of the countries in the analysis have low trade barriers and high volume of the international trade.

\subsection{Methodology}

The fundamental assumption regarding the validity of least square estimators is that the model error term should not be correlated with the regressor, i.e., $E(u / x)=0$. If this assumption fails, Ordinary Least Square (OLS) estimators are no longer valid and are biased; they do not allow consistent interpretation of the results. However, an Instrumental Variable (IV) estimator provides unbiased and consistent estimators under the assumption that valid instruments exist, where the instruments $\mathbf{z}$ are variables which are correlated with the regressors $\mathbf{x}$ (that are assumed to be endogenous), which satisfy $E(u / z)=0$. The IV method is an appropriate approach for estimating the parameters of models with endogenous regressors, as well as errors-in-variables models. Since, new growth theories assume that openness as endogenous variable rather than exogenous variable. And, financial development and growth may be mutually interdependent. Thus, we need to use IV method to capture endogeneitiy among certain variables.

Analysts may take the first difference of the model to control for unobserved country-specific effects, which cannot be handled using country-specific dummies because these are not directly observable. Also, if there is an endogeneitiy problem in the data, the estimator is capable of handling the simultaneity bias associated with the possible endogeneitiy of some of the explanatory variables. In this respect, one should use appropriate instruments that are related to the endogenous variable, but not correlated with the error term and other explanatory variables, to obtain unbiased and consistent estimates. There are two well-known IV models, known as 2-Stage Least Square (2SLS) and GMM models. Yet, while a 2SLS IV model uses instruments determined directly by the analysts, a GMM model uses lagged values of dependent variables automatically as its instruments. If the instruments selected are weakly exogenous variables, a 2SLS IV 
model may produce biased and inconsistent estimates. Contrary to 2SLS IV models, the GMM model as proposed by Arellano and Bond (1991) produces best-fit instruments by utilizing the orthogonally conditions that exist between lagged values of $y_{i t}$ and the disturbance vit. The method proceeds in several steps. We can illustrate this using our main specification, as follows:

$$
\text { Growth }_{i, t}=\beta_{0}+\beta_{1} \text { Growth }_{i, t-1}+\sum_{k=1}^{10} X_{k i t}+a_{i}+v_{i, t}
$$

In this case, Growth ${ }_{i, t}$ represents the GDP growth rate as of our dependent variable, while rrowth $_{i, t-1}$ refers to the lagged value of dependent variable. Furthermore, while $X_{k i t}$ indicates the explanatory variables and time dummies in the analysis, $a_{i}$ and $v_{i, t}$ refer to the individual effect (country effect) and disturbance term respectively. To eliminate the country effect, we should take the first difference of our specification. After taking the first difference, our specification is as follows:

$$
\Delta \text { Growth }_{i, t}=\Delta \beta_{1} \text { Growth }_{i, t-1}+\Delta \sum_{k=1}^{10} X_{k i t}+\Delta u_{i, t}
$$

Here, Growth $_{i, t}=$ Growth $_{i, t}-$ Growth $_{i, t-1}$ and so on, and $u_{i, t}=v_{i, t}-v_{i, t-1}$.

At this point, Arellano and Bond (1991) proposed to employ the lagged levels of the regressors as instruments. This approach is known as a difference GMM estimation, and is a feasible technique provided that the explanatory variables are weakly exogenous, and the error term is not serially correlated. The orthogonality of the moment conditions can be specified as follows:

$$
E\left[\operatorname{Growth}_{i, t-s} u_{i, t}\right]=0 \text { or } E\left[\operatorname{Growth}_{i, t-s}\left(v_{i, t}-v_{i, t-1}\right]=0 \text { for } \mathrm{s} \geq 2 ; t=3, \ldots, \mathrm{T} ; k=1, . ., 3\right.
$$

Furthermore, Arellano and Bover (1995) and Blundell and Bond (1998) suggest that the Arellano and Bond estimator will yield consistent and unbiased estimators unless the explanatory variables are intermittent. Otherwise, as the lagged levels of the variables become weak instruments, one should add additional moment conditions using the lagged first differences (LFDs).

These additional moment conditions can be specified as follows:

$$
E\left[\left(\text { Growth }_{i, t-s}-\text { Growth }_{i, t-s-1}\right)\left(\eta_{i i, t}+v_{i, t-1}\right]=0 \quad \text { for } s=1 ; k=1, . .3\right.
$$

For the $j^{\text {th }}$ endogenous regressor, the additional moment conditions can be specified as follows:

$$
E\left[\left(X_{j i, t-s}-X_{j i, t-s-1}\right)\left(\eta_{i}+v_{i, t}\right]=0, s=1 ; k=1, . ., 3\right.
$$

As we incorporate additional moment conditions into the model, we have what is called GMM system estimation (GMM-sys). While GMM system estimation yields superior estimators as compared to GMM in difference (GMM-diff) estimators, this technique may create over-identification problems among instruments and may thus weaken the efficiency of the tests. Nevertheless, we adopt this system approach, following Roodman's (2009) instrument reduction technique in imposing lag limits and collapsing the instrument matrix

The consistency of this estimator is contingent upon specification tests. The main test, also called the J test, was developed by Hansen (1982) and is a test of over-identifying restrictions. If the instruments are jointly valid under the null hypothesis, the empirical moments have zero expectations, such that the J statistic is distributed as a $\chi^{2}$ with the degrees of freedom being equal to the degree of over-identification. The other test (Arellano Bond AR (2) Test) checks the null hypothesis of no serial correlation of the differenced error term. In this test, a large $\mathrm{p}$ value is indicative of an appropriate specification of the model. 


\section{5- Empirical Findings}

To measure whether development of financial system weakens or strength the openness-growth relationship, we have employed one step system GMM specifications without interaction term and with interaction term for trade openness and financial development in Table 2 and Table 3 respectively. Furthermore, as three financial developments (financial dev1, financial dev2 and financial dev3) are highly correlated to each other; we have estimated three GMM-system specifications in each Table (Table 2 and Table 3) to avoid multicollinearity problems among variables. Three GMM-system specifications are prefixed as GMM1, GMM2 and GMM3 in Table 2 and Table 3. Moreover, we have conducted postestimations (Hansen Test and Arellano Bond AR (2) Test) to check the robustness of our estimates. With respect to the post-estimation test statistics, there is no second-order correlation in the error term and no over-identification problems in terms of number of instruments.

Table 2. Estimation Results without Interaction Term

\begin{tabular}{|c|c|c|c|}
\hline Variables & GMM1 & GMM2 & GMM3 \\
\hline Growth $\mathrm{t}-1$ & $\begin{array}{c}0.2401 \\
(0.000)^{* *}\end{array}$ & $\begin{array}{c}0.2397 \\
(0.000)^{* *}\end{array}$ & $\begin{array}{c}0.2417 \\
(0.000)^{* *}\end{array}$ \\
\hline Openness & $\begin{array}{l}-0.0063 \\
(0.269)\end{array}$ & $\begin{array}{l}-0.0040 \\
(0.579)\end{array}$ & $0.004^{* *}$ \\
\hline Financial Development 1 & $\begin{array}{l}-0.0087 \\
(0.223)\end{array}$ & - & - \\
\hline Financial Development 2 & 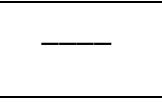 & $\begin{array}{l}-0.0136 \\
(0.172) \\
\end{array}$ & - \\
\hline Financial Development 3 & $\ldots$ & - & $\begin{array}{l}-0.0065 \\
(0.423) \\
\end{array}$ \\
\hline GDP per Capita & $\begin{array}{r}-0.0043 \\
(0.588) \\
\end{array}$ & $\begin{array}{l}-0.0026 \\
(0.687)\end{array}$ & $\begin{array}{l}-0.0048 \\
(0.432)\end{array}$ \\
\hline Human Capital & $\begin{array}{c}0.0429 \\
(0.039)^{*}\end{array}$ & $\begin{array}{c}0.0444 \\
(0.033)^{*}\end{array}$ & $\begin{array}{c}0.0451 \\
(0.030)^{*} \\
\end{array}$ \\
\hline Investment & $\begin{array}{c}0.1410 \\
(0.000)^{* *}\end{array}$ & $\begin{array}{c}0.1469 \\
(0.000)^{* *}\end{array}$ & $\begin{array}{c}0.1408 \\
(0.000)^{* *}\end{array}$ \\
\hline Inflation & $\begin{array}{l}-0.0689 \\
(0.028)^{*}\end{array}$ & $\begin{array}{l}-0.0697 \\
(0.028)^{*}\end{array}$ & $\begin{array}{l}-0.0684 \\
(0.030)^{*}\end{array}$ \\
\hline Dummy 2008 & $\begin{array}{l}-1.0684 \\
(0.039)^{*}\end{array}$ & $\begin{array}{l}-1.0754 \\
(0.039)^{*}\end{array}$ & $\begin{array}{l}-1.0531 \\
(0.041)^{*}\end{array}$ \\
\hline Dummy 2009 & $\begin{array}{l}-4.0599 \\
(0.000)^{* *}\end{array}$ & $\begin{array}{l}-4.0391 \\
(0.000)^{* *}\end{array}$ & $\begin{array}{l}-4.0479 \\
(0.000)^{* *}\end{array}$ \\
\hline Number of Observations & 779 & 779 & 779 \\
\hline Number of Instruments & 28 & 28 & 28 \\
\hline $\begin{array}{l}\text { Wald } \mathrm{Ch}_{2} \\
\text { Prob }>\mathrm{Ch}_{2}\end{array}$ & $\begin{array}{c}123.23 \\
(0.000)^{* *}\end{array}$ & $\begin{array}{c}117.32 \\
(0.000)^{* *}\end{array}$ & $\begin{array}{c}127.78 \\
(0.000)^{* *}\end{array}$ \\
\hline $\begin{array}{l}\text { Arellano Bond Test for } \\
\text { AR (2) }\end{array}$ & 0.106 & 0.107 & 0.113 \\
\hline Hansen Test & 0.112 & 0.108 & 0.110 \\
\hline
\end{tabular}


Table 3. Estimation Results with Interaction Term

\begin{tabular}{|l|c|c|c|}
\hline Variables & GMM1 & GMM2 & GMM3 \\
\hline Growth t-1 & 0.2414 & 0.2430 & 0.2413 \\
& $(0.000)^{* *}$ & $(0.004)^{* *}$ & - \\
\hline Interaction Term 1 & -0.00008 & - & - \\
\hline Interaction Term 2 & $(0.009)^{* *}$ & & - \\
& - & -0.00009 & \\
\hline Interaction Term 3 & & $(0.006)^{* *}$ & -0.00007 \\
& - & - & $(0.021)^{*}$ \\
\hline GDP per Capita & -0.0031 & -0.0028 & $(0.533)$ \\
\hline Human Capital & $(0.608)$ & $(0.644)$ & 0.0422 \\
& 0.0418 & 0.0438 & $(0.050)^{*}$ \\
\hline Investment & $(0.053)^{*}$ & $(0.042)^{*}$ & 0.1363 \\
& 0.1355 & 0.1376 & $(0.000)^{* *}$ \\
\hline Inflation & $(0.000)^{* *}$ & $(0.000)^{* *}$ & -0.0681 \\
& -0.0682 & -0.0683 & $(0.031)^{*}$ \\
\hline Dummy 2008 & $(0.030)^{*}$ & $(0.030)^{*}$ & -1.0633 \\
& -1.0710 & -1.0720 & $(0.033)$ \\
\hline Dummy 2009 & $(0.032)^{*}$ & $(0.032)^{*}$ & -4.0494 \\
& -4.0620 & -4.0619 & $(0.000)^{* *}$ \\
\hline Number of Observations & $(0.000)^{* *}$ & $(0.000)^{* *}$ & 779 \\
\hline Number of Instruments & 779 & 779 & 27 \\
\hline Wald Ch2 & & & 0.113 .33 \\
Prob>Ch2 & 27 & 27 & 0.104 \\
\hline Arellano Bond Test for & 108.57 & 110.13 & \\
AR (2) & $(0.000)^{* * *}$ & $(0.000)^{* *}$ & 0.115 \\
\hline Hansen Test & 0.110 & 0.102 & \\
\hline & 0.106 & & \\
\hline
\end{tabular}

As seen from Table 2 and Table 3, we could not find any evidence supporting the positive impact of trade openness and three types of financial developments (financial dev1, financial dev2 and financial dev3) on economic growth. Yet, we found that interaction terms for openness index and financial developments (Interaction Term 1, 2 and 3) have a negative significant impact on economic growth. In other words, while both trade openness and financial development don't lead to economic growth, their joint effect causes a negative impact on economic performance of the countries in the analysis. Possible explanation of this result may be attributed to the financial capital outflows which in turn may cause reduction in economic growth rates. In other saying, as the financial system develops, higher trade openness may induce investors to transfer financial capital to the rest of the world to receive higher rate of return on their investments. Thus, financial developments may weaken the contribution of trade openness to economic growth and more truly it may even worse the economic performance of the countries in the analysis.

On the other side, with respect to effects of control variables on economic growth, we have found robust results confirmed in both Table 2 and Table 3. We empirically proved that while human capital and gross capital formation (investments) are positively correlated with economic growth, inflation rate is negatively correlated with economic growth. In other words, as the female labor force participation rates in total labor force increases, economic growth rates are likely to increase. Furthermore, higher amounts of investments carried out by investors enhance the goods and services produced and thus lead to economic growth. Contrary to human capital and investments, higher inflation rates as an indicator of macroeconomic condition lowers the economic performance of the countries. 
Lastly, GFC represented by time dummies of 2008 and 2009 have a negative effect on the economic performance of the countries. More clearly, as expected, GFC emerged at the end of 2007's due to the real estate property collapse in USA affect the growth rates of the countries in the analysis negatively.

\section{6- Summary and Conclusions}

Even though, there are several studies examining the factors affecting the openness and growth nexus, many of those studies have neglected to measure the effects of financial development in determining the opennessgrowth relationship. Thus, the main objective of this study is to find out whether the financial development affects the contribution of openness to economic growth. Novelty of the study is three-folds: First, contrary to previous studies, this study employs one-step system GMM dynamic panel data method to capture endogeneitiy between growth, financial development and openness. Second, by using IV method that allows us to incorporate endogenous variables; we are able to figure out if financial development has any role in determining the contribution of openness to economic growth. Third, we are also able to predict to determine whether there is linkage between openness and economic growth or financial development and economic growth.

At the end of the study, we could not find any effect of trade openness or financial development on economic growth. Rather, we have found that interaction term representing the joint effect of three financial developments and openness has a negative effect on economic performance of the countries. We attributed this result to the willingness of investors to transfer their financial capital outflows as trade barriers lowers and financial system gets deeper. Furthermore, we have proved that human capital and investments have positive effects on economic growth while inflation rate and GFC worsen the economic performance of the countries.

With respect to the empirical results, we have important policy suggestions worth to note: Trade barriers are important for integration of countries with the rest of the world and they may affect the economic growth positively. At the same time, a developed financial system may induce investors to transfer financial capital to out which in turn lowers the economic growth. Therefore, policy makers should implement higher capital controls in the financial market to prevent financial capital transfers to the outside of the country. Rather, policy makers should try to attract capital inflows with a deeper financial system and lower trade barrier.

\section{REFERENCES}

Abramovitz, M. (1986). Catching up, forging ahead, and falling behind. Journal of Economic History, 46: 385406

Ades, A.F., and Glaeser, E. (1999). Evidence on growth, increasing returns and the extent of the market. Quarterly Journal of Economics, 114: 1025-1046.

Aghion, P., Howitt, P., and Mayor-Foulkes, D. (2005). The effect of financial development on convergence: Theory and evidence. Quarterly Journal of Economics, 120: 173-222.

Arellano, M. \& Bond., S. (1991). Some tests of specification for panel data: Monte Carlo evidence and an application to employment equations. The Review of Economic Studies, 58(2), 277-297.

Arellano, M. \& Bover, O. (1995). Another look at the instrumental variable estimation error components model. Journal of Econometrics, 68(1), 29-51.

Awokuse, T.O. (2008). Trade openness and economic growth: is growth export-led or import led?, Applied Economics, 40(2): 161-173.

Baldwin, R., Braconier, H., and Forslid, R. (2005). Multinationals, endogenous growth, and technological spill overs. Theory and evidence. Journal of Money, Credit and Banking, 33: 16-41.

Blundell, R., and Bond, S. (1998). Initial conditions and moment restrictions in dynamic panel data models. Journal of Econometrics, 87 (1), 115-143 
Dowrick, S., and Golley, J. (2004). Trade openness and growth: Who benefits? Oxford Review of Economic Policy, 20: 38-56.

Hansen, L.P (1982). Large sample properties of Generalized Method of Moment Estimators. Econometrica, 50(4), 1029-1054

Harrison, A. (1996). Openness and growth: A time series, cross country analysis for developing countries. Journal of Development Economics, 48: 419-447.

Howitt, P0. (2000). Endogenous growth and cross-country income differences. American Economic Review, 90: $111-130$

Huang, L.-C., and Chang, S.-H. (2014). Revisit the nexus of trade openness and GDP growth: Does the financial system matter? The Journal of International Trade \& Economic Development, 23 (7): 1038-1058.

Kaltani, L. (2007). Complementary reforms and the link between growth openness and growth in Albania. Post-Communist Economies, 19 (2): 225-253.

Keho, Y. (2017). The impact of trade openness on economic growth: The case of Cote d'Ivoire. Cogent Economics \& Finance, 5: 1-14.

Kim, D., and Lin, S. (2009). Trade and growth at different stages of economic development. Journal of Development Studies, 45: 1211-1224.

Kim, D.-H., Lin, S.-C., and Suen, Y.-B. (2012). The simultaneous evolution of economic growth, financial development, and trade openness. The Journal of International Trade \& Economic Development, 21 (4): 513-537.

Lucas, R.E. (1988). On the mechanic of economic development. Journal of Monetary Economics, 22: 3-42.

Ramanayake, S.S., and Lee, K. (2015). Does openness lead to sustained economic growth? Export growth versus other variables as determinants of economic growth. Journal of Asia Pacific Economy, 2 (3): 345368.

Rao, B.B. and Rao, M. (2009). Openness and growth in Fiji: Some time series evidence. Applied Economics, 41 (13): 1653-1662.

Redding, S. (1999). Dynamic comparative advantage and the welfare effects of trade. Oxford Economic Papers. 51:15-39.

Romer, P.M. (1989). Growth based on increasing returns due to the specialization. American Economic Review, 77: 56-62.

Rootman, D. (2009). How to do xtabond 2: An introduction to difference and system GMM in stata. The stata Journal 9(1), 86-136

Sakyi, D., Villaverde, J. and Maza, A. (2015). Trade openness, income levels, and economic growth: The case of developing countries, 1970-2009. The Journal of International Trade \& Economic Development, 26 (4): 860-882.

Sarkar, P. (2008). Trade openness and growth: is there any link? Journal of Economic Issues, 42: 763-785.

Stiglitz, J.E. (2004). Globalization and growth in emerging markets. Journal of Policy Modeling. 26: 465-484.

Ulaşan, B. (2015). Trade openness and economic growth: Panel evidence. Applied Economics Letters, 22 (2): 163-167.

Yenikkaya, H. (2003). Trade openness and economic growth: A cross-countries empirical investigation. Journal of Development Economics, 72: 57-89.

Young, A. (1991). Learning by doing and the dynamic effects of international trade. Quarterly Journal of Economics, 106: 369-405. 